\title{
Dönüşümsel Seyahat: Kaçkar Dağları Milli Parkı Örneği
}

Transformational Travel: Case of Kaçkar Mountains National Park

\author{
Özer Mesut ÖZÇELiK*, Ece ÖMÜRiş** \\ * (Sorumlu Yazar), Uzm., Akdeniz Üniversitesi Yerleşkesi, Dumlupınar Bulvarı, Turizm Fakültesi, 07058, Konyaaltı, Antalya. \\ E-posta: ozer_ozcelik@hotmail.com \\ ORCID: 0000-0002-4857-1836 \\ ** Dr. Öğr. Üyesi., Akdeniz Üniversitesi Yerleşkesi, Dumlupınar Bulvarı, Turizm Fakültesi, 07058, Konyaaltı, Antalya. \\ E-posta: eceomuris@akdeniz.edu.tr \\ ORCID: 0000-0002-1485-2816
}

MAKALE BILGILERI

Makale işlem bilgileri:

Gönderilme tarihi: 21 Ekim 2019

Düzeltme: 26 Aralık 2019

Kabul: 8 Ocak 2020

Anahtar sözcükler: Dönüşümsel seyahat, Dönüşümsel öğrenme,

Dönüşümsel turizm, Seyahat motivasyonu.

\section{ARTICLE INFO}

Article history:

Submitted: 21 October 2019

Resubmitted: 26 December 2019

Accepted: 8 January 2020

Key words: Transformational travel, Transformative learning, Transformational tourism, Travel motivations.

\begin{abstract}
ÖZ
Seyahate dayalı deneyimler bireylerin bilgi, tutum ve davranışlarında değişimlere yol açabilmektedir. Dönüșümsel seyahat turistlerde dönüșüme yol açabilen öğrenme ve kișisel gelișim gibi motivasyonlarla gerçekleștirilen seyahatleri ifade etmektedir. Bu çalışmanın amacı Kaçkar Milli Parkı'na seyahat eden bireylerin seyahat sonucunda edindikleri dönüşümü anlamaya çalışmaktır. Dönüşümsel Öğrenme Kuramı'na (Mezirow 1978) dayalı olarak geliştirilen bu çalışmada fenomenoloji yaklaşımı kullanılmıştır. Kaçkar Dağları Milli Parkı'nı ziyaret etmiș, 16 katıımcıyla yapılan mülakatlarla zengin ve derin veri sağlanmıştır. Katılımcıların seyahatleri sonucunda çevresel farkındalık, davranışsal değişim, kendini gerçekleştirme, kişisel gelişim, sosyal ve kültürel değişim, sağlık ve iyi oluş ve toplumsal fayda geliştirdikleri bulgulanmıştır. Çalışmada, Kaçkar Dağları Milli Parkı'nın dönüștürücü potansiyeli ile ilgili ipuçları elde edilerek ileriki çalıșmalara yol gösterebilecek öneriler ortaya konmuştur. Ayrıca bu çalışma, seyahatin bireyler üzerindeki dönüştürücü gücünü Kaçkar Dağları Milli Parkı özelinde tespit ederek, ulusal alanyazınını genişletme niteliğindedir.
\end{abstract}

\section{GiRiş}

İnsanlık tarihi kadar eski bir olgu olan seyahat zaman içerisinde toplumların vazgeçilmez bir parçası haline gelmiştir. Sürekli genişleyen ve küreselleşen turizm endüstrisi yeni turizm çeşitleri oluşturmakta ve bu çeşitliliğe bağlı olarak her istediğine erişebilen yeni turist tipleri geliştirmektedir. Turizm anlayışındaki değişime bağlı olarak eğlence, konfor ve rahatlama gibi turistlerin temel seyahat motivasyonları yerini bireyin kendisinde değişime yol açabilecek öğrenme, kendini gerçekleştirme, yeni yerler keşfetme, kişisel gelişim gibi yeni seyahat motivasyonlarına bırakmaktadır (Reisinger 2015). Değişim motivasyonuyla seyahat eden turistler genellikle ilham, özgünlük, aidiyet, değer ve anlam gibi psi- 
kolojik gereksinim arayışındadırlar (Binkhorst ve Tekker 2009). Kendini geliştirme motivasyonuyla seyahate çıkan birey, seyahat sürecinde edindiği deneyimlere dayalı köklü bir değişim geçirerek bireysel bir dönüşüm yaşar. İnsanlar arasında değerlerin, yaşam tarzının, kaynakların nasıl kullanıldığının, paranın ve zamanın nasıl harcandığının köklü bir değişim geçirmesi gerektiğini belirten Reisinger (2013a), insanın yaşama amacını ve anlamını öğrendiği, ekolojik farkındalığın arttığı, empati, insan hakları, eşitlik, barış gibi değerlerin öne çıktığ 1 yeni bir dünya için bu tür bir dönüşümün gerekliliğini vurgulamaktadır. Dolayısıyla turizm, ihtiyaç haline gelen bireysel dönüşümün gerçekleştirilmesini mümkün kılmaktadır.

Kottler (1998), bireyin algısını veya yaşam biçimini değiştirme potansiyeline sahip en güçlü aktivitenin seyahat olduğunu belirtmiştir. Bireyler yeni bir mekâna seyahat ettiğinde, bulundukları çevrenin dinamikleri bireysel dönüşümü tetiklemektedir (Reisinger 2013a). Farklı bir ortamda, edindiği deneyimlerle kendini farklı bir perspektiften inceleme fırsatı yakalayan birey, yeni bakış açıları edinir. Bireyin bu "bakış açısı" onun bireysel dönüşümünü yansıtmaktadır.

Uluslararası alanyazında, seyahat ve turizmin öğrenmeye katkıda bulunduğunu vurgulayan, bireysel gelişimini teşvik eden, eğitici ve dönüştürücü bir potansiyele sahip farklı turizm çeşitlerini temel alan çalışmalar yer almaktadır. Örneğin; sırt çantalı turizmi, gönüllü turizm, eğitim amaçlı seyahatler veya yurtdışında eğitim görme, ekoturizm veya doğa temelli turizm, ekstrem sporlar, yoga seyahati, kültür turizmi, inanç turizmi, kırsal turizm ve sağlık turizmi dönüştürücü potansiyele sahiptir (Noy 2004; Brown 2009; Brymer 2013; Lean vd. 2014). Seyahatin dönüştürücü rolü uluslararası alanyazında tartışılan bir kavram olmasına karşın bu rolün ulusal alanyazında yeterince karşılık bulmadığını söylemek mümkündür. Dolayısıyla, mevcut araştırmanın, dönüşümsel seyahat kavramını güncel bir araştırma konusu olarak ulusal alanyazında tartışılabilir seviyeye getirebileceği düşünülmektedir.

Seyahat deneyimi, bireyde kişisel bir dönüşüme yol açtığı gibi turist ve ev sahibi top- lum arasındaki sosyal etkileşim ve iletişim de ev sahibi toplum üzerinde bir dönüşüme yol açabilmektedir (Reisinger 2015). Turizmin toplum ve destinasyon üzerindeki artan etkisi, seyahat kolaylığına bağlı destinasyonların artması, turizmin sürdürülebilir olmayan bir şekilde ilerlemesi (MacLeod 2006) gibi nedenler dönüşümsel seyahat kavramının ve dönüşüm ihtiyacının önemini bir kez daha ortaya koymaktadır. Zira, dönüşümsel seyahatin belirli destinasyonlar için sürdürülebilir ekonomik, sosyo-kültürel ve çevresel kalkınma sağlayabileceği, dolayısıyla da turizm paydaşlarına sürdürülebilirliği sağlayabilmeleri adına dönüşümü teşvik eden yeni turistik ürünleri üretmede fikir oluşturabileceği düşünülmektedir.

Bu çalışma, mevcut alanyazında turist deneyiminin ne olduğunu araştıran çalışmalardan farklı olarak, turistlerin deneyimleri sonucunda değişen bireysel bakış açılarını ve davranış değişikliklerini açıklamaya çalışmaktadır. Kaçkar Dağları Milli Parkı'na yapılan seyahatin turistler üzerinde nasıl bir dönüştürücü etkiye yol açttğııı anlamaya çalışmak bu çalışmanın temel amacını oluşturmaktadır.

\section{ALANYAZIN TARAMASI}

\section{Dönüşümsel Öğrenme Kuramı}

Dönüşümsel öğrenme, bireyi, düşünce, duygu ve eylemlerinde derin bir yapısal değişime götürmektedir. Başka bir ifadeyle, bireyin yaşam biçimini radikal ve geri dönüşümsüz olarak değiştiren bir bilinç kaymasıdır (Morgan 2010). Bireyi daha iyi bir bireye dönüştüren bu dönüşümü, bireyin kendisi ve dünyası hakkında derin bir anlayış geliştirme, diğer insanlarla veya doğayla olan ilişkiler geliştirme, öz-farkındalık, alternatif yaşam biçimleri keşfetme, sosyal adalet, barış gibi meselelerde daha fazla duyarlı davranma vb. davranış değişiklikleri ile açıklamak mümkündür (O'Sullivan 2002). Deneyime dayalı olarak öğrenilen tüm bilgilerin sonucunda davranışsal değişime uğramayı Mezirow (1991), Dönüşümsel Öğrenme Kuramı üzerinden açıklamaktadır. Dönüşümsel öğrenme kura$\mathrm{m}$, bireylerin deneyimlerini nasil anlamlandırdıklarını veya deneyime özgü anlamları, dene- 
yimleme biçimini etkileyen yapıların doğasını, anlamların değişiminde yer alan dinamikleri ve anlam yapılarının nasıl değiştiğini açıklamaya çalışmaktadır. Bireyin inanç ve duygularının bağlamı konusunda farkındalık geliştirmesini, varsayımlarını eleştirmesini, alternatif bakış açılarının değerlendirilmesini, yeni bakış açısını benimseme kararı veya eski ile yeninin bir sentezini yapmayı, yeni bakış açısına göre harekete geçme becerisini ve yeni bakış açısını kişinin yaşamında daha geniş bağlamda uygulamasını kapsamaktadir (Mezirow 1991).

Bireyi dönüşümsel öğrenmeye teşvik eden ilk gereklilik içsel, kişisel bir krizdir ki Mezirow içsel krizi bireyin ikilem oluşturması olarak tanımlamaktadır (Mezirow ve Taylor 2009). İkilem oluşturma, bireyin beklentileri ve anlam yapilarıyla uyuşmayan bir deneyim ile karşılaşması durumunda ortaya çıkmaktadır. Bu durum, dönüşümsel öğrenmenin tetikleyicisi olarak da tanımlanabilmektedir. Bireyin korku, öfke, suçluluk duygusu ile kendini değerlendirmesi, bireyin ikilem oluşturduktan sonra eski bakış açısını incelediği aşamadır. Birey kendini değerlendirmesinin ardından eleştirel bakış açısıyla varsayımlarını değerlendirmektedir. Bunun sonucunda birey dönüşüm sürecine girdiğini fark eder. Bu durumu çevresiyle de paylaşabilmektedir. Dönüşüm sürecine girdikten sonra birey yeni roller, ilişkiler ve eylemler için yeni seçenekler keşfetmeye başlamaktadır. Girilen bu yeni sürecin devam edebilmesi için birey eylem planları yapmaktadır. Birey, planlarını gerçekleştirebilmek için yeni bilgi ve beceriler edinmeye çalışmaktadır. Edinilen bilgi ve becerileri yeni bir rolde deneyimlemek istemektedir (Adım 8). Deneyimin sonucu olarak bireyde kendine güven gelişir ve bu yeni rolü sürdürmek ister. Tüm aşamaların sonucunda kazandığı yeni perspektifleri, yeni rolünü yaşamına tamamen entegre eder.

\section{Dönüşümsel Seyahat}

Turizm, insanların düşünce ve davranışlarını değiştiren etkili bir araçtır (Lean 2009: Lean vd. 2014). Seyahat sırasında bireyin farklı kültürler, insanlar ve mekanlar tarafından etkilenmesi so- nucunda ortaya çıkan yeni bakış açısı, çoğu kez kişinin yaşamında uzun süreli etkiler bırakabilmektedir. Böylece bireyin bilgi, değer, tutum ve davranış yolu değişebilmektedir. Dolayısıyla dönüşümsel turizm aktiviteleri, niyet ve sonucun öncelikle eğlence ve rahatlama olduğu sıradan seyahat deneyimlerinden farklı olmaktadır (Kottler 1997).

Dönüşümsel turizmi deneyimin bir sonucu açısından tanımlayan Christie ve Mason (2003) "turistik deneyim elde eden bireylerin tutum ve değerleri üzerinde olumlu bir değişime yol açan turizm faaliyeti" şeklinde ifade etmiştir. Seyahati, "bilinçli olarak yaklaşıldığında, bireye özfarkındalık ve ruhsal deneyim kazandıran ve bireyin bilincini arttıran, geniş kapsamlı özgün ve eğlenceli bir yol" olarak tanımlayan Ross (2010), dönüştürücü seyahatleri dönüşümsel öğrenme kuramı çerçevesinde, bireyde fiziksel, ruhsal, duygusal veya bilişsel dönüşümler yaratmak için turist tarafından başlatılan sürdürülebilir yolculuk olarak tanımlamıştır.

Bireyde dönüşümün başlayabilmesi için seyahatinin bağımsız olması ve dönüşüm, öğrenme, yerel kültürle bütünleşme, bireyi düşünmeye iten aktivitelere katılma gibi motivasyonlarla gerçekleşmesi gerekmektedir (Tomljenovic vd. 2015). Dönüşüm sürecinin başlayabilmesi için süreci tetikleyen ilk aşamanın, ikilemin, bireyde oluşması gerekmektedir. Örneğin, bireyin farklı bir kültür, fiziksel çevre veya sosyal alışkanlıklarla karşılaşması, onu mevcut referans çerçevesine veya dünya görüşüne uyum sağlayamayacağ 1 bir bilişsel uyumsuzluğa götürür. Böylece referans çerçevelerinin yeniden biçimlendirilmesine yol açacak bir ikilem oluşur (Reisinger 2013). Dönüşüm esnasında birey, yalnızca ziyaret edilen destinasyon için bir duygu geliştirmez, aynı zamanda yerle ilgili derin bir kimlik duygusu oluşturarak kendini bu yere ait olarak hisseder. Dönüşümsel seyahat insanları gözyaşlarına boğabileceği, heyecanlandırabileceği, mutlu edebileceği, aydınlatabileceği ve insanların tüm yaşamını ve inanç sistemini değiştirebileceği bir deneyimdir (Reisinger 2013). 
Dönüşümü her ne kadar deneyim tetiklese de deneyimin gerçekleştiği mekân da dönüşümde etkilidir. Çünkü bazı turistik mekanlar dönüştürücü etkiye sahip olma özelliğini taşımaktadır. Bu yerlerde bulunan somut ve somut olmayan ögeler mekanlara anlam, değer ve duygu kazandırmaktadır. Örneğin bir destinasyonda bulunan binalar, manzaralar, yürüyüş rotaları, sanat eserleri veya yemekler ile o destinasyona ait değerler, festivaller, ritüeller bireyin deneyimine derin anlamlar katarak duygusal ve ruhsal gelişime katkıda bulunmaktadır (Reisinger 2013b). Zıt kültürlerle karşılaşmanın ve alışılmadık bir ortamda bulunmanın en güçlü dönüştürücü etkiye sahip olduğunu söyleyen Morgan (2010), bu deneyimlerin bireyin dünya görüşünü yeniden gözden geçirmesi ve bireysel dönüşümu için temel oluşturduğunu belirtmektedir.

Ross (2010), kutsal mekanlarda kalmak, doğada olmak ve onunla bağlantı kurmak, sürdürülebilir uygulamalara katılmak, kendini keşfetmeyi amaçlayan meditasyon vb. grup aktivitelerine katılmak, fiziksel olarak zorlu faaliyetlerde bulunmak gibi deneyimlerin dönüştürücü olabileceğini belirtmiştir. Sonuç olarak yeni çevreler, bireye onu bir şekilde zorlayabilecek yeni uyaranlar sağlayarak yeni bakış açıları kazanmasını sağlamaktadır. Bu açıdan dönüşümsel öğrenme kuramı, seyahatin dönüştürücü gücünü incelemek için uygun bir çerçeve oluşturmaktadır. Çünkü dönüşümsel turizm rutinden geçici bir kaçış sunan sıradan turizm deneyimlerinden farklı olarak, turiste değissim sağlayan bir anlayış sunmaktadır.

Alanyazın incelendiğinde özellikle son 10 yılda dönüşümsel seyahate ilişkin çalışmalar dikkat çekmektedir. Lean (2009), 22 katılımciyla gerçekleştirdiği nitel bir araştırmada seyahat deneyimlerinin uzun vadede bireylerin düşünce ve davranışı değiştirme potansiyeline sahip olduğunu, toplumsal değişimin ve sürdürülebilirliğin turizm aracıllğıyla gerçekleşebileceğini iddia etmektedir. Brown (2009) ise eğitim amaçlı seyahat eden bireylerin uyum sürecini keşfetmek için yaptığı etnografi çalışmasında özgüven artışı, yaşam önceliklerinin değişmesi gibi değişiklikler gözlemlemiştir. Brymer (2013), fenomenoloji çalişmasında doğada ekstrem spor motivasyonu ile seyahat eden turistlerin deneyimlerinin sonucunda, alçakgönüllülük, arttırılmış maneviyat, kişisel gelişim, cesaret, özgüven, empati ve çevresel farkındalık gibi davranışsal değişiklikler tespit etmiştir. Deniz aşırı ve uzun süreli seyahat eden sırt çantalılar üzerine gerçekleştirilen nitel çalışmada (Kanning 2013), seyahatin empati ve farkındalık, anlayış geliştirme ve kariyer ve yaşam tarzında değişiklik yapmak gibi gözle görülür davranışsal etkiler yarattığı ortaya koyulmuştur. Avustralya'daki ekoçiftlik ziyaretçilerinin incelendiği karma yöntem çalışmasında, bu deneyime katılmak çiftlik sahipleriyle daha derin ilişkiler kurmayı ve elde edilen deneyimin kendini geliştirmeyi, çevresel farkındalığı ve basit bir yaşam tarzı tercihini arttırdığını ortaya koymuştur (Deville ve Wearing, 2013). Alanyazından hareketle dönüşümsel seyahati, sırt çantalı, gönüllü, eğitim amaçlı veya ekoturizm aracllı̆̆ıyla gerçekleşen ve destinasyonun kültürüne dahil olma fırsatı sunan bir turizm türü olarak tanımlamak mümkündür (Tomljenovic vd. 2015). Mevcut çalışma ise sözü geçen çalışmalardan farklı olarak tek bir destinasyon çerçevesinde fakat birden fazla seyahat çeşidi dahil edilerek gerçekleştirilmiştir.

\section{YÖNTEM}

\section{Araştırmanın Yöntemi}

Bir destinasyona anlam, değer, duygu katan binalar, doğal güzellikler, yemekler gibi somut unsurlar ile kültür, ritüeller, ahlaki değerler gibi somut olmayan unsurlar insan deneyimini derinleştirerek kişisel gelişime katkıda bulunmaktadır. Örneğin; Vatikan, Auschwitz Toplama Kampı, Grand Canyon, Tac Mahal gibi belirli turistik yerlerin bireyler üzerinde dönüştürücü etkisi bulunmaktadır (Reisinger 2013b). Doğada gerçekleştirilen bir seyahat veya farklı kültürel gelenekleri, sınıfları, değerleri ve tutumları olan bir destinasyonda gerçekleştirilen seyahat dönüştürücü etkiye sahiptir (Morgan 2010). Bu bağlamda değerlendirildiğinde Kaçkar Dağları Milli Parkı'nın; yaban hayatı, bitki zenginliği, doğal yaşlı ormanları, manzarası, buzul vadi- 
leri, gölleri, şelaleleri, aktüel buzulları, hörgüç kayaları, moren setleri, eşsiz doğa güzellikleri, temiz havası, soğuk ve berrak kaynak suları, termal kaynakları, Kaçkar (3932m) zirveleri gibi jeomorfolojik, klimatik ve jeolojik oluşumları ile yayla meskenlerinin otantik mimarisi, yöre insanının misafirperverliği, geleneksel yaylacılık faaliyetleri, kamp yerleri, tarihî patika yolları, konakları, kültürel ve sosyo-ekonomik yapısı, yaşam biçimi gibi beşeri özellikleriyle (Zaman 2008) dönüştürücü bir potansiyele sahip olabileceği varsayılmaktadır. Bu bilgiler ışığında seyahatin bireyler üzerindeki dönüştürücü etkisinin yanı sıra seyahat edilen destinasyonun da dönüşüm sürecine etkisi olabileceği araştırmanın dayanak noktasını oluşturmaktadır. Dolayısıyla, bu çalışmanın amacı turistlerin Kaçkar Dağları Milli Parkı'na seyahat motivasyonlarını, seyahat sürecinde yaşadıkları deneyimleri ve sonucunda gerçekleştirdikleri seyahatin kendileri üzerindeki dönüştürücü etkisini anlamaya çalışmaktır. Araştırmanın amacına yönelik araştırma sorusu “Kaçkar Dağları Milli Parkı'nda seyahat etmek turistler üzerinde nasıl bir dönüştürücü etkiye sahiptir?" olarak geliştirilmiştir.

Kaçkar Dağları Milli Parkı'nı ziyaret eden turistlerin hangi motivasyonlara sahip oldukları, ne tür deneyimler elde ettikleri, dönüşüm sürecinin nasıl başladı $\breve{g}_{1}$, deneyimlerin sonucu olarak turistlerde nasıl dönüşümlerin gerçekleştiği gibi araştırmanın temelini oluşturan soruların cevabını aramak için nitel araştırma yaklaşımı tercih edilmiştir. Özellikle turist deneyimlerinin ontolojik yapısı gereği, gerçekliğin bakış açısına göre çeşitlilik göstermesi (Creswell 2013) ve bu deneyimlere bağlı olarak dönüşümleri anlama çabası bu çalışmanın niteliksel yönünü kuvvetlendirmiştir. Fenomenoloji yönteminin izlendiği araştırmada turistlerin Kaçkar Dağları Milli Parkı'nda edindikleri deneyimlere bağlı olarak gerçekleşen dönüşümlerinin evrensel niteliğini daha iyi anlayabilmek için turist deneyimlerini bir araya getirmek hedeflenmiştir.

Katılımcıların yaşanmış deneyimlerine ait zengin verilere ulaşmak amacıyla yarıyapılandırılmış görüşme formu oluşturulmuştur. Görüşme formu hazırlanırken ilgili alanyazın incelenmiştir. Sorular hazırlandıktan sonra uzman görüş formu hazırlanmış ve nitel araştırma yöntemlerinde deneyimli uzmanlardan görüş alınmıştır. Uzmanlardan gelen görüş ve öneriler doğrultusunda gerekli düzeltmeler yapılarak katılımcılara sorulacak nihai görüşme soruları belirlenmiştir. Görüşme yapılacak kişilerin yabancı uyruklu olabilecekleri öngörüsüyle görüşme soruları İngilizce veya Türkçe dillerinde geliştirilmiştir.

\section{Örneklem ve Veri Geliştirme}

Creswell'e (2013) göre fenomenoloji araştırmalarında katılımcıların araştırılan fenomenle ilgili deneyimlere sahip olması gerektiğinden kriter (ölçüt) temelli örneklem bu tür çalışmalarda en uygun örnekleme yöntemidir. Araştırmanın amacı doğrultusunda, katılımcıların seyahatlerinde Kaçkar Dağları Milli Parkı'nı ziyaret etmiş olmaları, seyahatleri esnasında tırmanış, trekking, rafting, kültür turu gibi belirli aktivitelerden en az birini deneyimlemiş olmaları ve bölgede en az dört gün konaklamış olmaları örneklem kriterleri olarak belirlenmiştir. $\mathrm{Bu}$ kriterlerin her birine uyan bireylere ulaşmak güç olduğundan ihtiyaç duyulduğunda kartopu örnekleme yöntemine başvurulmuştur. Kaçkar Dağları Milli Parkı turistler arasında popüler bir cazibe merkezi olduğundan, katılımcılar seyahatleri esnasında birçok farklı turistle tanışabilme, birlikte seyahat edebilme gibi firsatlar yakalayabilmektedir. Dolayısıyla, daha fazla örnekleme ulaşabilmek amacıyla katılımcılardan kriterleri taşıyan turistleri önermesi kartopu örnekleme yöntemiyle mümkün olmuştur.

Toplamda 22 katılımcıyla gerçekleştirilen çalışmada 19 katılımcıdan yüzyüze görüşme yöntemi ile üç katılımcıdan ise e-posta yolu ile veri sağlanmıştır. Kaçkar Dağları Milli Parkı'nda dönüşüm fenomenini açıklayamayan veya tam anlaşılamayan yanıtlar veren altı katılımcıya ait veriler araştırma kapsamından çıkarılmıştır (Tablo 1). Yüzyüze görüşmeler toplam 350 dakika sürmüsstür. Bu süreye e-posta yoluyla gerçekleştirilen görüşmeler dahil değildir. Yüzyüze görüşülen bütün katılımcılarla yapılan görüşmeler Kaçkar Dağları Milli Parkı seyahatleri 
sonrası gerçekleştirilmiştir. Kaçkar Dağları Milli Parkı'nda seyahatleri esnasında ulaşılan bazı turistlere katılımcı olup olamayacakları sorulmuş, olumlu cevap veren katılımcilara seyahatleri sonrası e-posta yoluyla ulaşılarak görüşmeler sağlanmıştır. Yüzyüze yapılan görüşmelerin verimli bir şekilde gerçekleştirilebilmesi açısından katılımcıların rahat bir şekilde deneyimlerini aktarabileceği ve katılımcıların istekleri doğrultusunda belirlenen mekânlar (doğa, yayla evi, pansiyon, park, kafe vb.) seçilmiştir. Katılımcıların izniyle görüşmeler ses kayıt cihazıyla kaydedilmiştir.

\section{Veri Analizi}

Bu araştırmada Moustakas'in (1994) fenomenoloji araştırmalarında veri analizi için önerdiği, araştırmacının deneyimin özünü açıklamasını sağlayan, katılımcı için önemli olan faktörleri tanımlamasına izin veren görüşmelerden temalar bulma yöntemi benimsenmiştir. Bu kapsamda yüzyüze görüşmelerden elde edilen ses kayıtlarının deşifre edilerek metin haline getirilmesi ve e-posta yoluyla elde edilen verilerin düzenlenmesi sonucunda 60 sayfalık ham veri elde edilmiştir. Verilerin kodlanması aşamasına geçmeden önce Kaçkar Dağları Milli Parkı'nda seyahat eden turist deneyimlerine bağlı olarak gerçekleşen dönüşüm fenomeninin anlaşılması amacıyla metinler tek tek ve defalarca okunmuştur. Fenomenin özünü açıklayabileceği düşünülen önemli ifadeler belirlenerek bağlam dışı kalan ifadeler araştırma kapsamından çıkartılmıştır. Veri hakkında derin bir anlayışa varıldıktan sonra katılımcıların Kaçkar Dağları Milli Parkı'nda yaşadıkları seyahat deneyimin özünü yansıttığı düşünülen ifadeler kodlanmıştır. Araştırmanın temaları Wolf vd.'nin (2017) çalışmasında ortaya çıkardığı yedi farklı tema temel alınarak oluşturulmuştur: Çevresel farkındalık, davranışsal değişim, kendini gerçekleştirme, kişisel gelişim, sosyal ve kültürel değişim, sağlık ve iyi oluş ve toplumsal fayda. Ek olarak araştırmacı tarafından uygun temaları açılayan

Tablo 1. Görüşme Yapılan Katılımcıların Demografik Özellikleri

\begin{tabular}{llllllr}
\hline Katılımıı & Yaş & Cinsiyet & Uyruk & Eğitim & Seyahat Türü & $\begin{array}{r}\text { Veri Toplama } \\
\text { Yöntemi }\end{array}$ \\
\hline Zeki & 26 & Erkek & Türk & Lisans & Sırt çantalı & Yüz yüze \\
\hline Elli & 27 & Kadın & Alman & Master & Sırt çantalı & E-Posta \\
\hline Muhammet & 25 & Erkek & Türk & Lisans & Sırt çantalı & Yüz yüze \\
\hline Burak & 26 & Erkek & Türk & Lisans & Sırt çantalı & Yüz yüze \\
\hline Kübra & 24 & Kadın & Türk & Lisans & Sırt çantalı & Yüz yüze \\
\hline Mike & 54 & Erkek & İngiliz & Master & Ekoturizm & Yüz yüze \\
\hline Jane & 57 & Kadın & İngiliz & Lise & Ekoturizm & Yüz yüze \\
\hline Martin & 56 & Erkek & Avustralyalı & Lise & Ekoturizm & Yüz yüze \\
\hline Alex & 52 & Kadın & Avustralyalı & Lisans & Ekoturizm & Yüz yüze \\
\hline Ayşen & 27 & Kadın & Türk & Master & Ekoturizm & Yüz yüze \\
\hline Fulya & 27 & Kadın & Türk & Master & Ekoturizm & Yüz yüze \\
\hline Kirsten & 28 & Kadın & Avustralyalı & Master & Sırt çantalı & Yüz yüze \\
\hline Crystal & 28 & Kadın & Avustralyalı & Master & Sırt çantalı & Yüz yüze \\
\hline Buket & 28 & Kadın & Türk & Doktora & Gönüllü Turizmi & E-posta \\
\hline Didem & 26 & Kadın & Türk & Master & Ekoturizm & Yüz yüze \\
\hline Ela & 27 & Kadın & Türk & Lisans & Ekoturizm & Yüz yüze \\
\hline
\end{tabular}


ifadeler ile görüşüne başvurulan iki uzmanın belirlediği temalar karşılaştırılmıştır. İki araştırmacı arasındaki karşılaştırmalı uyuşmanın güvenirliğini ölçen Kappa tutarlılık katsayısı ,72 düzeyinde yeterli bulunmuştur (Landis ve Koch 1977).

\section{Geçerlilik ve İnandırıcılık}

Araştırmacının araştırmaya dair yanlılığı, nitel araştırmaların geçerliliği için son derece ciddi bir tehdit oluşturmaktadır (Onwuegbuzie ve Leech 2007). Miles ve Huberman (2014) yanlılığın, araştırmacının araştırma üzerinde ve araştırmanın araştırmacı üzerinde olmak üzere iki şekilde etki edebileceğini belirtmiştir. Araştırmadaki yanlılığı en aza indirgemek için, öncelikle, araştırmacıların uzun süre araştırma alanında kalmaları geçerlilik açısından önemlidir (Creswell ve Miller 2000). Bu sayede araştırmacı katılımcılara ve katılımcıların mekânlarına ulaşabilmektedir. Alanda uzun süre vakit geçiren araştırmacı ile katılımcılar daha kolay güven bağ 1 kurarak daha fazla veri sunabilmektedir. Araştırmanın veri toplama sürecinde alanda bir yıldan fazla bulunulmuş ve örneklem kriterleri dikkate alınarak, titiz bir şekilde katılımcılara ulaşılmıştır. Ayrıca araştırmacının heterojen bir örneklem seçimi yapmaktan kaçınması, araştırmacının yerelleşmekten kaçınması, kavramsal çerçeveye bağlı kalması, uzman incelemesinden faydalanması araştırmanın araştırmacı üzerindeki etkisini azalttığı belirtilmiştir (Miles ve Huberman 2014). Dolayısıyla, her bir katılımcıya çalışmanın amacı, görüşmelerin nasıl yapılacağı ile ilgili detaylar açık bir şekilde ifade edilmiştir. Örneklem seçimi esnasında sadece önceden belirlenen örneklem kritlerleri dikkate alınmış ve araştırmanın homojenliğine yüksek önem verilmiştir. Ayrıca araştırma sürecinde kavramsal çerçeveye sadık kalınmıştır.

\section{BULGULAR}

Dönüşümsel öğrenme kuramına göre dönüşümün ilk aşaması ikilem oluşturmadır (Mezirow 1991). Katılımcıların seyahatleri sürecinde kendilerinde dönüşümü tetikleyen ve kendilerini ikilem oluşturmaya sürükleyen yerel halk ile etkileşimde bulunmak, diğer gezginlerle etkileşimde bulunmak ve doğa ile etkileşimde bulunmak gibi deneyimler yaşadıkları belirlenmiştir. Katılmcılar ikilem oluşturan deneyimlerini çoğunlukla bölgenin coğrafi yapısından, seyahat ederken doğa karşısında hayrete düştüklerinden, adrenalin hissettiklerinden, doğa yürüyüşlerinden veya ilk defa gerçekleştirdikleri bir deneyimden söz etmektedirler.

Dönüşüm sürecinin devam etmesi için bireyin kendi kendini inceleme, yeni davranış biçimleri için seçenekler keşfetme, yetkinlik ve özgüven kazanma, bilgi edinme ve eylem becerileri kazanma, kazandıkları yeni rolleri deneyimleme ve yeni bir bakış açısıyla topluma yeniden entegre olabilme gibi bir dizi aşamadan geçmesi gerekmektedir (Mezirow 1991). Katılımcilar ile yapılan görüşmelerden alınan alıntılar katılımcılardaki değişimin dönüşüm seviyesinde gerçekleştiğini kanıtlar niteliktedir. Dönüşümlerin belirgin bir biçimde açılanabilmesi için temalar kullanılmıştır. Kaçkar Dağları Milli Parkı deneyimlerinin sonucunda dönüşüme bağlı olarak turistlerde ortaya çıkan yerel halka saygı, çevreye duyarlılık, minnet duygusu gibi olumlu değişimler çevresel farkındalık olarak temalandırılmıştır. Bölgeyi ziyaret eden insanların doğayı kirletmeleri, çöplerini bırakmaları, yerel halkı yok saymaları ve buna bağlı olarak yerel halkın mevcut durumdan rahatsız olması gibi durumlarla karşılaşan turistlerde çevresel farkındalık bulgulanmıştır.

...çöpünü herkes bıraktığı için inekler buzağılar zarar görmüş, hayvanını kaybeden insan var ya. Benim gelmeden önce düşündü̆̆̈̈m işte bir yayla kültürü var, yayla turizmi var ama herkes serinlemek için çıkıyor sanıyordum. Ama halbuki öyle değilmiş, büyükbaş hayvanın otlatmaya gidiyor herkes. Yaylacilar bu durumdan son yillarda çok rahatsız olmaya başlamıs. Onları dinleyince onlar gibi düşünmeye başlıyorsun, böyle bir korumacı oluyorsun sanki senin yaylanmış gibi... (Muhammet)

Kaçkar Dağları Milli Parkı deneyimlerinin sonucunda dönüşüme bağlı olarak turistlerde meydana gelen belirgin davranış değişiklikleri davranışsal değişim olarak temalandırılmıştır. Turistlerin Kaçkar Dağları karşısında hayrete 
düşmeleri, ilk defa doğa temelli bir seyahat deneyimlemeleri veya yerel halktan gördükleri tutumun bir sonucu olarak davranışlarında değişim gözlemlenmiştir.

\begin{abstract}
...yakın gelecekte doğayla iç içe olan bir hayat kurmak istiyorum ve şimdi bu hayata yatırım yapmaya başlayacağım. Beton yığınları arasında kalmak değil dağda, kırlarda olmak ve insanları da bu güzelliklere çekmek istiyorum. Böyle fikirlerle ve dinlenmiş bir zihinle döndüm. Şunu gördüm evet böyle kendi ellerimle güzel bir işletmem olabilir ileride. Bu bağlamda yeni fikirlerle döndüm İstanbul'a. Şu anda somut bir amactm var. Kaoslu ve stresli bulduğum şehir yaşamından kaçmalıyım ve bu kaçıs doğaya, yine insanlarla irtibat halinde olacă̆ $ı m$, seyahat edebileceğim güzel bir coğrafyaya olmalı... (Buket)
\end{abstract}

Kaçkar Dağları Milli Parkı deneyimlerine bağlı olarak turistlerin hayallerini gerçekleştirme, belirlediği bir hedefe ulaşma, korkularını yenme gibi kazanımlar kendini gerçekleştirme olarak temalandırılmıştır.

\footnotetext{
...Hayatımda hiç bu kadar yüksek rakıma tırmanmamıştım, bunu yapabildiğimi görmek farklı bir duygu. Benim eskiden yükseklik korkum vardl. Kemerlinin dik bir yapısı var. Oraya zirve olmasa da epey tırmandım. Eskiden çok korkardım yüksekten,

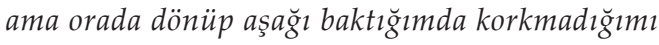
fark ettim. Yükseklik korkumu orada bıraktım..." (Zeki)
}

Kaçkar Dağları Milli Parkı deneyimlerinin sonucunda dönüşüme bağlı olarak turistlerde meydana gelen beceri geliştirme, perspektif kazanma, özgüven artışı, öz farkındalık gibi olumlu değişimler kişisel gelişim olarak temalandırılmıştır. Seyahatlerinde fiziksel veya duygusal olarak zorlu deneyimler gerçekleştiren, bu deneyimlerden olumlu kazanımlar elde eden turistlerin kendilerini geliştirdikleri bulgulanmıştır.

\footnotetext{
Diğer seyahatlerime göre farkl, yürüyüşlerden ziyade şehir gezdiğim için, konaklama olsun gezi olsun onlar daha kolay tabi onu fark ettim... Burada buzula tirmanacaksin, yayla yayla gezeceksin daha fazla zorlanıyor insan. Ateş yakma mesela, burası daha nemli oluyor bu defa ateş yakmak için, yayladaki insanlardan kuru odun istiyorsun veya diğer seyahatlerde bu kadar yă̆mura yakalanmıyorsun, ayakkabıların ıslanmıyor, ayakkabıyı kurutmak
}

için yöntemler geliştirdim. Diğer seyahatler daha kolaymış onu fark ettim. Ege Akdeniz'de bu kadar zorlanmıyorsun... Öyle bir faydası oldu. Zorluklarla mücadele etmeyi öğrendik, başa çıkmayı... (Muhammet)

Kaçkar Dağları Milli Parkı deneyimlerinin sonucunda turistlerin yeni sosyal çevrelere girmesi, yeni ilişkiler kurma, bölgeye dair kültür, yaşam, tarih vb. hakkında sosyal ve entelektüel birikimi arttıran katkılar sosyal ve kültürel gelişim olarak temalandırılmıştır. Seyahatleri esnasında yerel halkla ve diğer turistlerle etkileşim halinde olan turistlerin sosyal ve kültürel açıdan geliştikleri tespit edilmiştir.

...Türkiye'de etnik bir grup olan Hemşin halkını öğrendim. Biraz şaşırttı. Bu bölgede Türkiye'nin geri kalanına kıyasla eşsiz bir kültür var. Çünkü Avustralya'da herkes birbirinin aynısı gibi yaşıyor. O da çok eski bir ülke değil... (Kirsten)

Kaçkar Dağları Milli Parkı deneyimlerinin sonucunda dönüşüme bağlı olarak turistlerde meydana gelen fiziksel değişimler, iyileşme, stresten kurtulma, mutlu olma gibi olumlu etkiler sağgllk ve iyi oluş olarak temalandırılmıştır. Deneyimlerinin bir sonucu olarak dinlenmiş, rahatlamış bir şekilde hayatlarına devam eden turistlerde sağlık ve iyi oluş gözlemlenmiştir.

\footnotetext{
...bu seyahatin ardından zihnen acayip rahatlamış hissediyorum. Kafamdaki bir sürü karmaşa o yollarda son buldu. Dinlenmiş bir zihinle döndüm. Ayrica bedenen dinç hissediyorum. Oksijen beni gerçekten diri tuttu, bunu hissedebiliyorum... (Buket)
}

Kaçkar Dağları Milli Parkı seyahatlerinin sonucunda tavsiyede bulunma, diğer insanlara ilham verme, yardımseverlik gibi toplumsal fayda sağlayacak davranışlarda bulunması toplumsal fayda olarak temalandırılmıştır.

... Ama kemerli Kaçkar o doğanın yapısı, o taşların nasıl oluştuğu onu görmek, başka bir deneyim. Ileride insanlara bir şeyler anlatırken, bu deneyimleri anlatacă̆ım. Orası benim alanımı genişletti, yeni bir şey kazandım. Alanım ne kadar genişletirsen, diğer insanlara o kadar fazla şey kazandırırsın. İham olursun onlara... (Zeki) 
...yani yalnız da çıksan, mesela ben yalnız seyahat ediyordum buraya gelirken ama hiç arkadaşsız kalmadım. Sürekli birileriyle yardımlaştım. Yardımlaşma duygusu bende ön plana çıktı Kaçkar seyahatimde... (Burak)

\section{SONUÇ}

$\mathrm{Bu}$ çalışma, dönüşümsel öğrenme kuramı çerçevesinde birbirinden farklı seyahat motivasyonlarıyla seyahat eden turistlerin Kaçkar Dağları Milli Parkı'ndaki deneyimlerini ve bu deneyimlerin turistler üzerindeki dönüştürücü etkisini açıklamaya çalışmaktadır. Kaçkar Dağları Milli Parkı, içerisinde barındırdığı somut ve somut olmayan unsurları ile turistlere eşsiz deneyim fırsatları sunmaktadır. Bu yönüyle dönüştürücü potansiyele sahip olduğu ve turistler üzerinde önemli dönüştürücü etkiler bıraktığ 1 düşünülmektedir. Zira, Reisinger (2013b), yaban hayatını, doğayı deneyimleyen insanlarda olumlu yönde bir dönüşüm gerçekleştiğini aktarmaktadır. Wearing (2001), doğanın bireylere unutulmaz deneyimler sunduğunu belirtmiştir. Rengarenk bir günbatımına tanık olmak, bir s1radağın ihtişamını izlemek, dağda bir çobanla sohbet etmek insanlarda dönüşümü tetikleyen bir katalizör görevi görebilmektedir. Bu tür eşsiz manzaralar insanları, düşünmeye, sınırlarını fark etmeye ve kendisinden daha büyük bir gücün varlığı karşısında daha mütevazı olmaya itmektedir. Dönüşümsel öğrenme kuramının ilk aşaması olan ikilem oluşturma Kaçkar Dağları Milli Parkında seyahat eden, tırmanış, rafting, kamp, yürüyüş gibi aktivitelere katılan turistlerde çevresel farkındalık, davranışsal değişim, kendini gerçekleştirme, kişisel gelişim, sosyal ve kültürel değişim, sağlık ve iyi oluş ile toplumsal fayda gibi olumlu dönüşümler bulgulanmıştır. Dolay1sıyla Kaçkar Dağları Milli Parkı'nın dönüştürücü potansiyele sahip olduğunu ifade etmek mümkündür.

Araştırmanın demografik bulguları incelendiğinde Kaçkar Dağları Milli Parkı'na seyahat eden turistlerin farklı seyahat motivasyonlarına sahip olduklarını ve tercih ettikleri seyahat türlerinin farklılıklar gösterdiği anlaşılmaktadır. Dönüşümsel seyahat alanyazını seya- hat türleri çerçevesinde incelendiğinde çalışmaya katılan turistlerin tercih ettikleri turizm çeşitlerinin dönüştürücü potansiyele sahip olduğu görülmektedir. Sırtçantalı turistler üzerine yapılan dönüşümsel seyahat araştırmalarında empati, farkındalık, yaşam tarzında değişiklik, kalıcı benlik değişimleri, özgürlük, kişisel gelişim, kendini gerçekleştirme (Noy 2004; O'Reilly 2006; Kanning 2013); ekoturizm çalışmalarında çevresel farkındalık, davranışsal değişim, fiziksel ve psikolojik güçlenme, kişisel gelişim, sosyal ve kültürel değişim (Ballantyne vd. 2011; Deville ve Wearing, 2013); gönüllü turizm çalışmalarında ise kişisel gelişim, kendini gerçekleştirme, sağlık, bağımsızlık, öz-farkındalık, yeni bilgi ve becerilerin kazanılması ve ilişki geliştirme (Coghlan ve Gooch 2011) gibi bulgular tespit edilmiştir. Sıralanan bulgular mevcut araştırmanın bulgularıyla paralellik göstermektedir. Buradan hareketle, turistlerin Kaçkar Dağları Milli Parkına seyahat etmelerinin yanı sıra tercih ettikleri seyahat türünün de dönüşümlerini etkilediği söylenebilir.

Turizm bir boş zaman faaliyeti olmanın yanı sıra, yeni paradigmaları oluşturan, sosyal ve kültürel değişimlere yol açan ve bireyleri daha sürdürülebilir bir turizm davranışına sürükleyen bir olgudur. Alanyazın, seyahat ve turizmin öğretici, ufuk açıcı, anlayış geliştiren, kişisel gelişimi destekleyen, eğitici ve dönüştürücü potansiyele sahip olduğunu kabul etmektedir. Belirli turistik destinasyonlar, mekanlar, doğal alanlar, milli parklar gibi cazibe merkezleri dönüştürücü güce sahiptir. Bu bağlamda mevcut çalışmada Kaçkar Dağları Milli Parkı'nın dönüştürücü potansiyeli irdelenmiştir. Kaçkar Dağları Milli Parkı'nı farklı seyahat motivasyonlarıyla seyahat eden turistlerin benzer dönüşümler göstermesi Kaçkarların dönüştürücü niteliğini kuvvetlendirmektedir. Kaçkar Dağları Milli Parkı'nda seyahat eden turistlerde ortaya çıkan olumlu dönüşümler göz önüne alındığında, turistlerin artan duyarlılıklarını davranışlarına yansıtarak çevreye karşı daha sorumlu hale geldiklerini söylemek mümkündür. Kaçkar Dağları Milli Parkı'nın ekolojik sürdürülebilirliği düşünüldüğünde bu durumun olumlu bir sonuç ortaya koyduğu yadsınamaz. Turistlerin davranış değişikliklerini seyahat sonrası 
yaşamlarına uyarlayacağı bakışıyla daha küresel bir etkiden de söz etmek mümkündür.

Çalışmanın katkılarının yanı sıra sınırlılıklar1 da mevcuttur. Öncelikle, doğru örnekleme ulaşabilmek adına kriter temelli örnekleme yöntemi ile belirli kriterler çerçevesinde katılımcılarla görüşmeler sağlanmıştır. Ancak katılımcıların kendi dönüşümlerini keşfedebilmeleri ve açıklayabilmeleri adına seyahatlerinin üzerinden ne kadar süre geçmesi gerektiği bilinememektedir, tespit de edilememektedir. Dolayısıyla görüşmelere katılan bazı turistlerle seyahatlerinin hemen sonrasında görüşmeler gerçekleştirildiğinden dönüşümlerine ilişkin geleceğe yönelik tahmini bulgulara ulaşılmıştır. Ayrıca araştırmada yer alan katılımcı sayısı bir fenomenoloji çalışması için yeterli görünse de mevcut çalışmada yer alan her bir katılımcının özgün deneyimlere sahip olması nedeniyle katılımcı sayısının arttırılmasının bir sonraki çalışmaları zenginleştireceği düşünülmektedir.

\section{DEĞERLENDIRME}

Dönüşümsel seyahat kavramı özellikle uluslararası alanyazında güncel araştırma alanlarından biri olarak öne çıkmaktadır. Bu çalışmanın ulusal alanyazına özgün katkılar sağlayacağı ve dönüşümsel seyahat ile ilgili kavramsal anlayış1mızı genişleteceği düşünülmektedir. Dolayısıyla araştırmacıların bu alanda ulusal alanyazına katkıda bulunması ve kavramı tartışılabilmesi gelecek çalışmalara yön verebilmesi açısından önemlidir. Ayrıca, dönüşümsel öğrenme kuramının belirli bir turizm çeşidine uyarlanmasının turizm çalışmaları için bir model teşkil edebileceği varsayılmaktadır. Dönüşümsel seyahat kavramına yönelik çalışmalar genellikle niteliksel yöntemler çerçevesinde araştırılmıştır. Kavramın daha net açıklanması ve kavram üzerindeki kavrayışın sağlamlaştırılması için karma yöntem uygulamalarının daha etkili olabileceği düşünülmektedir. Çalışma sadece Kaçkar Dağları'nda seyahat eden turistlerle gerçekleştirilmiş olup bölgedeki yerel halk, işletmeler gibi turizmin diğer paydaşlarının da dönüşümlerinin araştırılması gelecek çalışmalar için yol gösterici olabilir. Son olarak, dönüşümsel seyahatin çevresel duyarlılığı arttırdığı göz önüne alındığında bu alanda yapılacak çalışmaların turizmin sürdürülebilirliğine katkı sağlayabileceği göz önünde bulundurulmalidir.

\section{KAYNAKÇA}

Ballantyne, R. Packer, J. ve Sutherland, L. A. (2011). Visitors' Memories of Wildlife Tourism: Implications for the Design of Powerful Interpretive Experiences, Tourism $\mathrm{Ma}$ nagement, 32 (4): 770-779.

Binkhorst, E. ve Den Dekker, T. (2009). Agenda for CoCreation Tourism Experience Research, Journal of Hospitality Marketing \& Management, 18 (2-3): 311-327.

Brown, L. (2009). The Transformative Power of the International Sojourn: An Ethnographic Study of the International Student Experience, Annals of Tourism Research, 36 (3): 502- 521.

Brymer, E. (2013). Extreme Sports as Transformational Tourism. İçinde Y. Reisinger (Editör), Transformational Tourism: Tourist Perspectives (ss. 111-124). Londra: CABI.

Christie, M. F. ve Mason, P. A. (2003). Transformative Tour Guiding: Training Tour Guides To Be Critically Reflective Practitioners, Journal of Ecotourism, 2 (1): 1-16.

Coghlan, A. ve Gooch, M. (2011). Applying a Transformative Learning Framework to Volunteer Tourism, Journal of Sustainable Tourism, 19 (6): 713-728.

Creswell, J. W. ve Miller, D. L. (2000). Determining Validity in Qualitative Inquiry, Theory Into Practice, 39 (3): 124-130.

Creswell, John W. (2013). Qualitative Inquiry and Research Design: Choosing Among Five Approaches (Üçüncü Baskı.). Kaliforniya: Thousand Oaks, Sage.

Deville, A. ve Wearing, S. (2013). Wwoofing Tourists: Beaten Tracks and Transformational Paths. İçinde, Y. Reisinger (Editör), Transformational Tourism: Tourist Perspectives (ss. 151-168). Londra: CABI.

Kanning, M. (2013). Returning Home: Reflections on Lifestyle Transformation Resulting From International Backpacker Travels. İçinde, Y. Reisinger (Editör), Transformational Tourism: Tourist Perspectives (ss. 125-135). Londra: CABI.

Kottler, J. A. (1997). Travel That Can Change Your Life: How to Create a Transformative Experience. San Fransisco: Jossey-Bass.

Kottler, J. A. (1998). Transformative Travel, The Futurist, 32 (3): 24.

Landis, J.R. ve Koch, G.G. (1977). The Measurement of Observer Agreement for Categorical Data, Biometrics, 33 (1): 159-174.

Lean, G. (2009) Transformative Travel: Inspiring Sustainability. İçinde R. Bushell ve P. Sheldon (Editörler), Wellness and Tourism: Mind, Body, Spirit, Place (ss. 191-205). New York: Cognizant.

Lean, G., Staiff, R. ve Waterton, E. (2014). Exploring Travel and Transformation. Travel and Transformation. Londra: Routledge. 
Macleod, N. (2006). Cultural Tourism: Aspects of Authenticity and Commodification. İçinde, M. Robinson ve A. Phipps (Editörler), Cultural Tourism in a Changing World: Politics, Participation and (Re) Presentation (ss. 177-190). Clevedon: Channel View.

Mezirow, J. (1978). Perspective Transformation, Adult Education, 28 (2): 100-110.

Mezirow, J. (1991). Transformative Dimensions of Adult Learning. San Francisco: Jossey-Bass.

Mezirow, J. ve Taylor, E. W. (2009). Transformative Learning in Practice: Insights from Community, Workplace, and Higher Education. San Fransisco: Jossey-Bass.

Miles, M. B. ve Huberman, A. M., (2014). Qualitative Data Analysis: A Methods Sourcebook. Kaliforniya: Thousand Oaks, Sage.

Morgan, A. D. (2010). “Journeys into Transformation: Travel to an "Other" Place as a Vehicle for Transformative Learning", Journal of Transformative Education, 8 (4): 246268.

Moustakas, C. (1994). Phenomenological Research Methods. Kaliforniya: Sage.

Noy, C. (2004). This Trip Really Changed Me: Backpackers' Narratives of Self-Change, Annals of Tourism Research, 31(1): 78-102.

O'reilly, C. C. (2006). From Drifter to Gap Year Tourist: Mainstreaming Backpacker Travel, Annals of Tourism Research, 33 (4): 998-1017.

O'sullivan, E. (2002). The Project and Vision of Transformative Education. İçinde, E. O'sullivan ve A. Morrell (Editörler), Expanding the Boundaries of Transformative Learning: Essays on Theory and Praxis (ss. 1-12). New York: Palgrave Macmillan.
Onwuegbuzie, A. J. ve Leech, N. L. (2007). “Validity and Qualitative Research: An Oxymoron?, Quality \& Quantity, 41 (2):233-249.

Reisinger, Y. (2013a). Transformation and Transformational Learning Theory. İçinde, Y. Reisinger (Editör), Transformational Tourism: Tourist Perspectives (ss.17-26). Londra: CABI.

Reisinger, Y. (2013b). Connection between Travel, Tourism and Transformation. İçinde; Y. Reisinger (Editör), Transformational Tourism: Tourist Perspectives (ss. 27-32). Londra: CABI.

Reisinger, Y. (2015). Personal Transformation and Travel and Tourism. İçinde, Transformational Tourism: Host Perspectives (ss. 6-13). Londra, CABI.

Ross, S. L. (2010). Transformative Travel: An Enjoyable Way to Foster Radical Change, Revision, 32 (1): 54-61.

Tomljenović, R. Ateljević, I. Đukić, L. ve Senkić, M. (2015). Transtourism-Operational Definition and Typology of Transformative Travel Experiences, http://www. transtourism.com/perch/resources/Files/a1o2-tt-workingdefinition-and-typology.pdf, Erişim tarihi: 15 Mayıs 2019.

Wearing, S. (2001). Volunteer Tourism: Experiences That Make a Difference. Londra: CABI.

Wolf, I. D. Ainsworth, G. B. ve Crowley, J. (2017). Transformative Travel as a Sustainable Market Niche for Protected Areas: A New Development, Marketing and Conservation Model, Journal of Sustainable Tourism, 25 (11): 1650-1673.

Zaman, M. (2008). Fırtına Deresi Havzası ve Kaçkar Dağları Milli Parkı'nın Alternatif Turizm Açısından Önemi, Atatürk Üniversitesi Sosyal Bilimler Enstitüsü Dergisi, 12(2): 1-33.

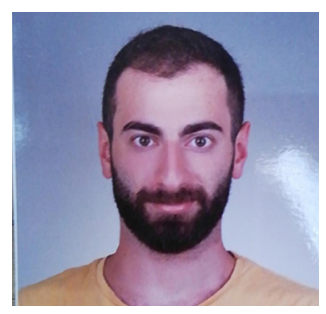

Özer Mesut ÖzÇELIK

Akdeniz Üniversitesi Turizm Fakültesi Seyahat İşletmeciliği Bölümü’nden mezun oldu (2015). Yüksek lisans derecesini Akdeniz Üniversitesi'nde Turizm İşletmeciliği ve Otelcilik Dalı’ndan (2019) aldı. Halen Akdeniz Üniversitesi, Sosyal Bilimler Enstitüsü, Turizm İşletmeciliği ve Otelcilik alanında doktora öğrenimine devam etmektedir (2019).

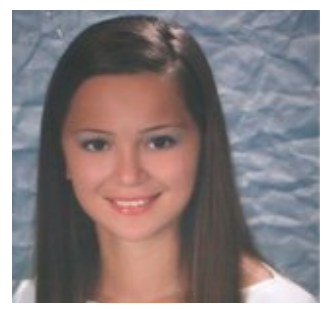

Ece ÖMÜRiş

Akdeniz Üniversitesi Turizm İşletmeciliği ve Otelcilik Yüksekokulu'ndan mezun oldu (2004). Yüksek lisans derecesini Akdeniz Üniversitesi'nden Turizm Işsletmeciliği ve Otelcilik Dalı'ndan (2007), doktora derecesini de Akdeniz Üniversitesi'nden Turizm İşletmeciliği ve Otelcilik Dalı́ndan aldı (2014). Akdeniz Üniversitesi'nde çalışmaya başladı (2015). Halen Akdeniz Üniversitesi Turizm Fakültesi'nde görev yapmaktadır. Temel çalışma alanları, örgütsel davranış ve turizm işletmeciliğidir. 